University of Nebraska - Lincoln

DigitalCommons@University of Nebraska - Lincoln

Bait matrix flavor preference by mongoose (Herpestes auropunctatus) in Puerto Rico: Implications for Oral Rabies Vaccination

\author{
Are R. Berentsen \\ USDA/APHIS/WS/National Wildlife Research Center \\ Shylo R. Johnson \\ USDA/APHIS/WS/National Wildlife Research Center
}

Kurt C. VerCauteren

USDA-APHIS-Wildlife Services, kurt.c.vercauteren@usda.gov

Follow this and additional works at: https://digitalcommons.unl.edu/icwdm_usdanwrc

Part of the Life Sciences Commons

Berentsen, Are R.; Johnson, Shylo R.; and VerCauteren, Kurt C., "Bait matrix flavor preference by mongoose (Herpestes auropunctatus) in Puerto Rico: Implications for Oral Rabies Vaccination" (2014). USDA Wildlife Services - Staff Publications. 1445.

https://digitalcommons.unl.edu/icwdm_usdanwrc/1445

This Article is brought to you for free and open access by the U.S. Department of Agriculture: Animal and Plant Health Inspection Service at DigitalCommons@University of Nebraska - Lincoln. It has been accepted for inclusion in USDA Wildlife Services - Staff Publications by an authorized administrator of DigitalCommons@University of Nebraska - Lincoln. 


\title{
Bait matrix flavor preference by mongoose (Herpestes auropunctatus) in Puerto Rico: Implications for Oral Rabies Vaccination
}

\author{
Are R. Berentsen *, Shylo R. Johnson and Kurt C. VerCauteren \\ USDA/APHIS/WS/National Wildlife Research Center, 4101 LaPorte Ave., Fort Collins, Colorado, 80521. \\ *Corresponding author: Are.R.Berentsen@aphis.usda.gov
}

\begin{abstract}
The small Indian mongoose (Herpestes auropunctatus) is the primary rabies vector in Puerto Rico. Mongooses are implicated in up to $74 \%$ of rabies cases on the island, and pose a threat to domestic animals and human health and safety. No rabies management program exists in Puerto Rico and development of an oral rabies vaccination program requires determining which flavors on the vaccine's bait coating matrix that are attractive to mongooses. Our objective was to evaluate preference among three flavors (cheese, coconut and fish) in the Ultralite bait matrix that is used for delivery of Rabies Vaccine, Live Adenovirus Vector (ONRAB ${ }^{\circledR}$ ). Placebo baits were offered to free-ranging mongooses in two different ecological environments. The study was conducted at EI Yunque National Forest and Cabo Rojo National Wildlife Refuge. At each site we established bait stations with three bait flavors offered simultaneously. We placed a remote camera at each station to monitor bait fate. Cheese ranked higher than fish flavor (W=1473, $P$ $=0.0273)$ and cheese and fish both ranked significantly higher than coconut $(W=2180.5, P<0.0001$ and $W=2065.0$, $\mathbf{P}=\mathbf{0 . 0 0 0 8}$, respectively). These results suggest cheese and fish flavors should perform better than coconut flavor in attracting free-ranging mongooses to consume ONRAB ${ }^{\circledR}$ baits in Puerto Rico.
\end{abstract}

Keywords. - Cabo Rojo National Wildlife Refuge, Caribbean, El Yunque National Forest, wildlife diseases

The introduced range of the small Indian mongoose (Herpestes auropunctatus) includes dozens of islands in the Pacific and Caribbean (Hoagland and Kilpatrick 1999). Originally introduced to tropical islands to control rat (Rattus spp.) populations and thus reduce damage to sugar cane plantations (Espeut 1882; Nellis and Everard 1983; Hoagland et al. 1989), mongooses are now considered a pest. They failed at suppressing rat populations and now prey on native species (Seaman and Randall 1962; Nellis and Everard 1983). The mongoose has also emerged as a public health threat. Mongooses are rabies reservoirs in some regions and in Puerto Rico comprise up to $74 \%$ of rabies cases on the island (Blanton et al. 2012) with the remaining $26 \%$ found in domestic animals. Recent serology suggests that up to $40 \%$ of mongooses in some regions of Puerto Rico have been exposed to rabies virus (A. Berentsen, 2013, unpublished data). This is similar to reports from Grenada, where the prevalence of rabies neutralizing antibodies in mongooses ranged from 3 to 55\% (Everard and Everard 1985). Wildlife vaccination has never occurred in Puerto Rico and development and implementation of a program requires research to determine the most appropriate mongoose attractant flavor to include in the baits.

In the United States the National Rabies Management Program (NRMP) manages rabies in wildlife through oral rabies vaccination (ORV). Target species include grey foxes (Urocyon cinereoargenteus), raccoons (Procyon lotor) and coyotes (Canis latrans) (Slate et al. 2005). However, the vaccine-bait currently used for ORV in the United States is ineffective in some terrestrial species, including mongooses (Blanton et al. 2006). Blanton et al. (2006) successfully vaccinated mongooses using an experimental vaccine. Creekmore et al. (1994) found that placebo oral rabies vaccine baits reached up to $97 \%$ of mongooses on their study sites in the Caribbean. These findings suggest that oral vaccination of mongooses may be possible with a suitable vaccinebait combination. The Rabies Vaccine, Live Adenovirus Vector $\left(\mathrm{ONRAB}^{\circledR}\right)$, contained in the Ultralite bait, has been used in Canada (Artemis Technologies Inc. Ontario) to vaccinate striped skunks (Mephitis mephitis) and raccoons represented a prospective candidate for this study. For example, research suggests the $\mathrm{ONRAB}^{\circledR}$ bait is more effective at vaccinating 
raccoons and skunks in Canada than the vaccine currently used in the United States (Mainguy et al. 2013, Fehlner-Gardiner et al. 2012). Currently, it is unknown whether mongooses will ingest $\mathrm{ONRAB}^{\circledR}$ baits or what flavor is the most effective attractant. In a previous study on bait selection in mongooses, Pitt and Sugihara (2009) found no apparent selection difference among four food-based baits, although fish and coconut baits were visited more often than other baits. Linhart et al. (1993) documented similar results in four different manufactured foodflavored baits. We evaluated preference among three flavors (cheese, coconut and fish) of bait matrix used with the Ultralite bait, when offered to free-ranging mongooses in two different ecological environments in Puerto Rico: El Yunque National Forest (YNF) and Cabo Rojo National Wildlife Refuge (CR).

El Yunque National Forest encompasses 11,331 ha of mountainous, rugged terrain approximately $40 \mathrm{~km}$ southeast of San Juan, Puerto Rico (Figure 1). Habitat consists largely of subtropical rainforest. Average annual rainfall is approximately $300 \mathrm{~cm}$ and generally occurs from May-October, although rains are frequent throughout the year (Quinn and Whisson 2005). Our study was conducted in approximately 25 $\mathrm{km}^{2}$ of the Palo Colorado region and included an extensive network of hiking trails and paved roads.

Cabo Rojo National Wildlife Refuge consists of 751 ha located on the southwestern side of Puerto Rico (Figure 2). The region is subtropical dry forest, with flat to gently sloping terrain dominated by forest/scrub and grassland habitats. Average rainfall is approximately $100 \mathrm{~cm}$ annually (Weaver and Schwagerl 2008). This study was conducted in the spring, a period of relatively dry weather, corresponding to conditions during which ORV is conducted in Texas for gray fox and coyote rabies management.

We obtained water-filled placebo Ultralite baits composed of a blister pack with an external waxy coating (Artemis Technologies Inc., Guelph, Ontario, Canada). The body of the blister pack is an elongated oval with dimensions of $30 \times 14 \times 10 \mathrm{~mm}$ and a rectangular lip extending to $40 \times 20 \mathrm{~mm}$ (Rosatte et al. 2009). Approximately $75-80 \%$ of the external coating is composed of food-grade partially hydrogenated vegetable shortening, Microbond ${ }^{\circledR}$ wax, stearine and vegetable oil. The remaining $20-25 \%$ is a flavor matrix composed of foodderived products such as dried cheddar cheese, fish meal and dried coconut milk, depending on the desired flavor. This composition is advantageous as Sugihara (2009) found foodbased baits were more effective than artificial scents. Artificial flavors constitute $\leq 1.0 \%$ of the overall flavor matrix (A. Bereseford, Artemis Techologies Inc., pers. Comm.). We evaluated three food-based flavors (fish, cheese and coconut) that were found to be attractive to mongooses in previous studies in Hawaii (Pitt and Sugihara, 2009) and Antigua, West Indies (Linhart et al. 1993). Baits were manufactured by Artemis Technologies Inc., between January and March, 2012 and refrigerated until used.

We established up to 30 bait stations at each study site. We separated stations by at least $200 \mathrm{~m}$ to try to reduce the potential for the same mongoose visiting multiple stations. This distance was based on mean squared distance from centers of activity described in Quinn and Whisson (2005). Stations were established in the morning to allow the maximum amount of daylight exposure to take advantage of mongoose diurnal activity patterns. Each station consisted of a camera (Trophy Cams Model 119466, Bushnell, Overland Park, KS) and three baits (one of each flavor) placed in individual polystyrene dishes $(8.12 \times 8.12 \times 2.54 \mathrm{~cm}$ each $)$ with a small hole in the bottom to allow rain water to escape. Each camera was assigned one of three possible bait arrangements. We angled the cameras towards baits and located the camera approximately $0.75 \mathrm{~m}$ from the center bait. We monitored stations for seven days at each site (15-22 March 2012 for YNF, 7-14 May 2012 for CR). We checked cameras daily and exchanged memory cards as needed. We recorded bait condition (present, absent, chewed, etc.) for each bait type. In cases where baits had been disturbed (chewed upon, removed), we moved 


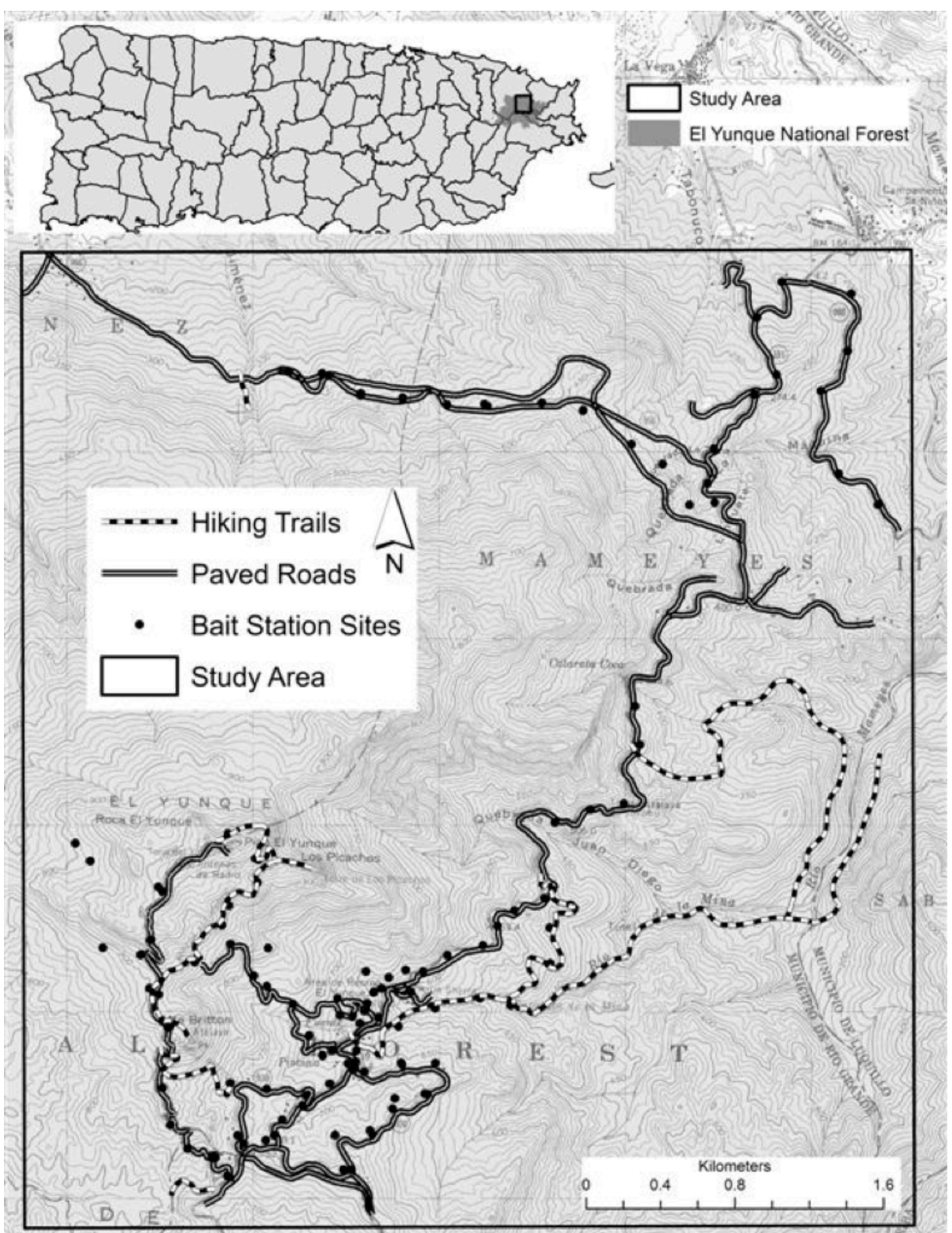

Fig. 1. Location of El Yunque National Forest study site, Puerto Rico, showing all bait station locations. March, 2012. 


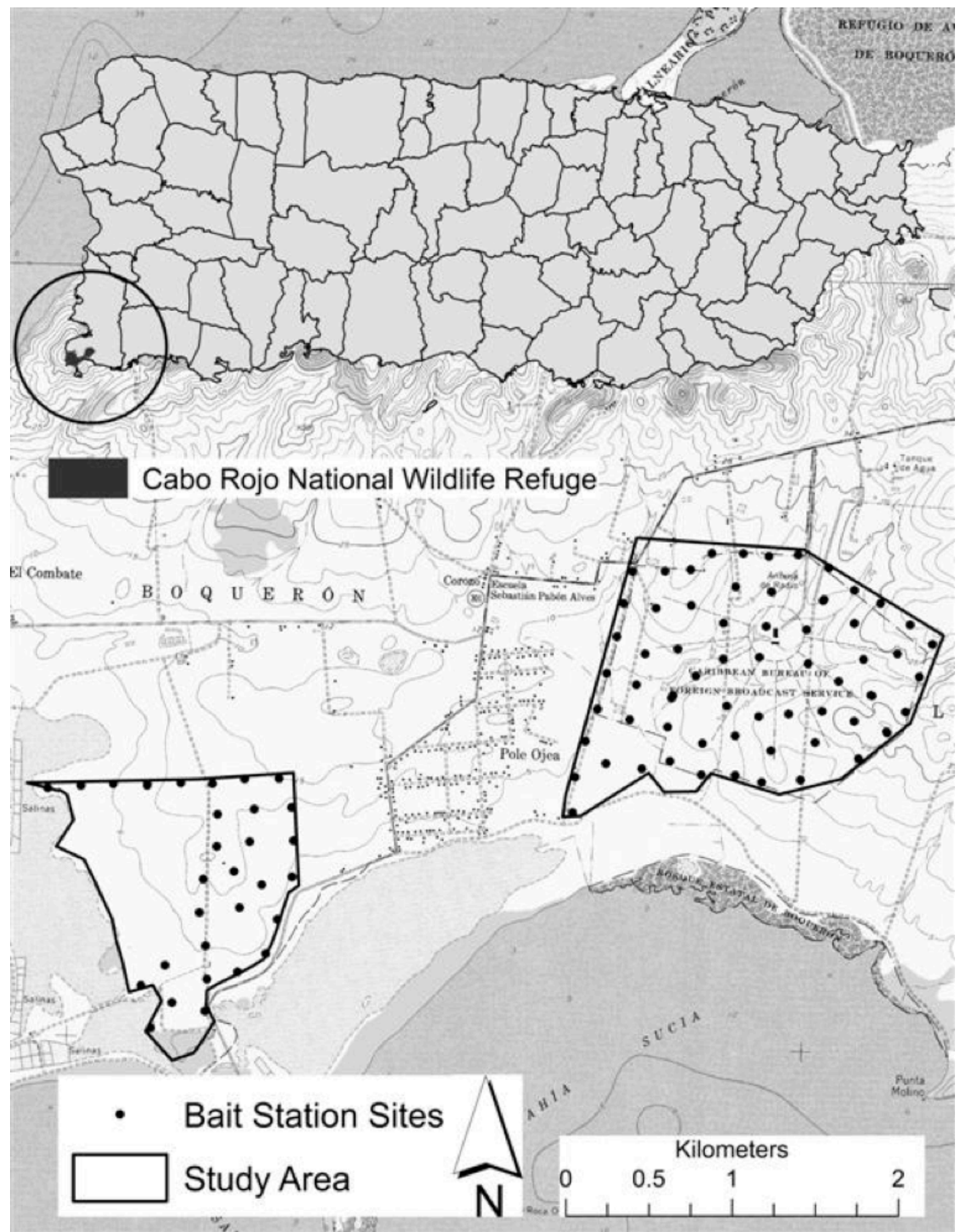

FIg. 2. Location of Cabo Rojo National Wildlife Refuge study site, Puerto Rico, showing all bait station locations. May, 2012. 
the camera station $\geq 200$ meters away from any current camera station and re-baited it with three fresh baits. At YNF, if no bait had been disturbed after 24 hours, the station was left in place for an additional 24 hours and then moved regardless of activity. Because of the relative small size of the CR site, if no bait had been disturbed after 24 hours, the bait station was re-baited and left in place until bait activity was recorded or until the end of the study. We programmed cameras to capture 60 seconds of video footage with a one second interval between activation events.

We reviewed the video footage and compared mongoose activity with the recorded bait condition to determine, if possible, which species was responsible for bait removal or disturbance. We classified, ranked and summed bait removal by mongooses following Saunders and Harris (2000) (Table 1). Inclusion for analysis was based on the following criteria:

All three bait types must be present and in camera view during the first recorded mongoose visit.

TABLE 1. Bait rankings (adapted from Saunders and Harris 2000).

Description Class

Bait removed first

5

Bait removed second

Bait removed third

3

Bait chewed/not removed

2

1

Bait investigated only

No interaction
Mongooses must have interacted with or consumed $\geq 1$ bait.

If individual baits were investigated multiple times, the behavior exhibiting the highest rank was assigned (i.e., removal is ranked higher than sniffing). Ranks were compared using Friedman's analysis of variance for ranked data adjusted for ties (Saunders and Harris 2000, Hollander and Wolfe 1973) using the FREQ procedure in SAS. We compared individual bait types using the Wilcoxon rank sum test (Hollander and Wolfe 1973) using the NPAR1WAY procedure in SAS (SAS Institute, Cary, North Carolina, USA). Statistical significance was $\mathrm{P}<0.05$.

Baits were monitored for 322 station nights at YNF and CR, combined. Video analysis revealed baits were removed by mongooses at $70(21.7 \%)$ stations, although only $41(12.7 \%)$ station nights me $t$ the criteria for analysis (Table 2). Bait type had a significant effect (Friedman's $\mathrm{S}=16.8289, \mathrm{P}=0.0002)$. Cheese ranked higher than fish flavor $(\mathrm{W}=1473, \mathrm{P}=0.0273)$. Cheese and fish both ranked significantly higher

TABLE 2. Rank sums of each bait type at two locations: overall and by study site.

Bait Type

Location/Ranks

Fish Cheese Coconut

\begin{tabular}{llll}
\hline Overall Total & 131 & 159 & 95
\end{tabular}

Rank

21

3

YNF Total

$81 \quad 97$

48

Rank

21

3

CR Total

$50 \quad 62$

47

Rank

21

3 
than coconut $(\mathrm{W}=2180.5, \mathrm{P}<0.0001$ and $\mathrm{W}$ $=2065.0, \mathrm{P}=0.0008$, respectively). Because of the ecological differences between the two study sites, we also evaluated results at each site individually.

At El Yunque National Forest baits were monitored for 133 station nights. All baits were removed during $85(63.9 \%)$ station nights and 1-2 were removed at $34(25.6 \%)$ station nights. No baits were removed during 14 (10.5\%) station nights. Of station nights where bait was removed, we were unable to identify the species responsible in $29(24.3 \%)$ station nights and apparent camera failures resulted in no images on the camera during 15 (11.3\%) station nights. Mongooses were captured on video interacting with baits during $43(32.3 \%)$ station nights, but only $23(17.3 \%)$ station nights met the criteria for analysis. Cheese had the highest overall rank, followed by fish and coconut (Table 2). There was a significant overall treatment effect (Friedman's $\mathrm{S}=16.1136, \mathrm{P}=$ 0.0003). Cheese ranked higher than fish flavor $(\mathrm{W}=444.0, \mathrm{P}=0.0279)$. Cheese and fish both ranked significantly higher than coconut $(\mathrm{W}=$ 743.5, $\mathrm{P}<0.0001$ and $\mathrm{W}=681.5, \mathrm{P}=0.0023$, respectively).

At Cabo Rojo National Wildlife Refuge baits were monitored for 189 station nights. All baits were removed during $26(13.8 \%)$ station nights, 1-2 were gone during 56 (29.6\%) station nights and zero were removed during $107(56.6 \%)$ station nights. Of station nights where bait was removed, we were unable to identify the species responsible in $31(37.8 \%)$ station nights and apparent camera failures resulted in no images on the camera during $12(6.3 \%)$ station nights. Mongooses were captured on video during $27(14.3 \%)$ station nights, but only $18(9.5 \%)$ station nights met the criteria for analysis. There was no overall bait effect (Friedman's $\mathrm{S}=$ $2.6250, \mathrm{P}=0.2691)$. Cheese ranked higher than fish flavor (Table 2), but the difference was not significant $(\mathrm{W}=310.00, \mathrm{P}=0.4602)$. Cheese and fish ranked higher than coconut but these differences were not statistically significant $(\mathrm{W}=385.00, \mathrm{P}=0.0974$ and $\mathrm{W}=380.00, \mathrm{P}=$ 0.1373 , respectively).
Black rats were the most common nontarget species that removed or otherwise interacted with bait. Rats removed at least one bait during $81(25.2 \%)$ station nights across both study sites. Other non-target species that removed baits included one domestic cat (Felis catus), one domestic dog (Canis familiaris), and one pearly eyed thrasher (Margarops fuscatus). During $20(10.6 \%)$ station checks at CR, bait coating had melted, but four of these stations still had bait missing. Baits were also observed infested with fire ants (Solenopsis sp.) during 38 $(20.1 \%)$ daily bait station checks, 11 of which also had baits removed. These phenomena were not observed at YNF but the influence, or lack thereof, of melted bait coating and fire ants on bait uptake requires study.

Our results suggest that among the flavors we evaluated, either cheese or fish flavor could be used as an ORV bait for mongooses in both ecosystems in Puerto Rico but cheese flavor performed better at YNF. Our study was limited by high levels of non-target removal of baits by rats and some technical difficulties with the use of the remote cameras resulting in lost data. Also, we did not evaluate the potential visual attractions that polystyrene dishes may have had. In addition our criteria for data analysis likely resulted in underestimated bait removal by mongooses. However, we believe this work provides a foundation for future research. Future research topics should include: additional flavor trials during multiple seasons with and without potential visual attractants, techniques to increase bait uptake by mongooses while reducing availability to rats, an evaluation of bait handling behavior and consumption by mongooses and vaccine effectiveness.

Acknowledgements.-The authors thank P. Quinones, F. Cano, B. Fuentes, and A. Gomez, for exceptional field assistance. Thanks also to F. Boyd and O. Diaz for logistic support and R. Engeman for statistical guidance. This study was approved by the USDA National Wildlife Research Center's Institutional Animal Care and Use Committee under protocol QA-1963.

$\mathrm{ONRAB}^{\circledR}$ - registered mark - Province of Ontario. 


\section{Literature Cited}

Blanton, J. D., A. Meadows, S. M. Murphy, J. Manangan, C. A. Hanlon, M. Faber, B. Dietzschold and C. E. Rupprecht. 2006. Vaccination of small Asian mongoose (Herpestes javanicus) against rabies. $J$. Wildlife Dis. 42:663-666.

Blanton, J. D., J. Dyer, J. McBrayer, and C. E. Rupprecht. 2012. Rabies surveillance in the United States during 2011. J. Am. Vet. Med. Assoc. 241:712-722.

Creekmore, T. E., S. B. Linhart, J. L. Corn, M. D. Whitney, B. D. Snyder, and V. F. Nettles. 1994. Field evaluation of baits and baiting strategies for delivering oral vaccine to mongooses in Antigua, West Indies. J. Wildlife Dis. 30:497-505.

Espeut, W. B. 1882. On the acclimatization of the Indian Mungoos in Jamaica. P.Zool. Soc. Lond. 1882:712714.

Everard, C. O. R., and J. D. Everard. 1985. Mongoose rabies in Grenada. In Population dynamics of rabies in wildlife, ed. P. J. Bacon, 43-69. London: Academic Press.

Fehlner-Gardiner, C., R. Rudd, D. Donovan, D. Slate, L. Kempf, and J. Badcock. 2012. Comparing $\mathrm{ONRAB}^{\circledR}$ and RABORAL V-RG ${ }^{\circledR}$ oral rabies vaccine field performance in raccoons and striped skunks, New Brunswick, Canada, and Maine, USA. J. Wildlif. Dis. 48:157-167.

Hoagland, D. B., G. R. Horst, and C. W. Kilpatrick. 1989. Biogeography and population biology of the mongoose in the West Indies. In Biogeography of the West Indies, past, present and future, ed. C. A. Woods, 611-634. Gainesville, Florida: Sandhill Crane Press, Florida Museum of Natural History.

Hoagland, D. B., and C. W. Kilpatrick. 1999. Genetic varaiation and differentiation among insular population of the small Indian mongoose (Herpestes javanicus). J. Mammal. 80:169-179.

Hollander, M., and D. A. Wolfe. 1973. Nonparametric statistical methods. New York: John Wiley \& Sons.

Linhart, S. B., T. E. Creekmore, J. L. Corn, M. D. Whitney, B. D. Snyder, and V. F. Nettles. 1993. Evaluation of baits for oral rabies vaccination of mongooses: pilot field trials in Antigua, West Indies. J. Wildlife Dis. 29:90-294.

Mainguy, J., C. Fehlner-Gardiner, D. Slate, and R. Rudd. 2013. Oral rabies vaccination in raccoons: Comparison of ONRAB ${ }^{\circledR}$ and RABORAL V-RG ${ }^{\circledR}$ vaccine-bait field performance in Québec, Canada, and Vermont, USA. J. Wildlife Dis. 49:190-193.

Nellis, D. W., and C. O. R. Everard. 1983. The biology of the mongoose in the Caribbean. Studies on the fauna of Curacao and other Caribbean Islands. Foundation for Scientific Research in Surinam and the Netherlands Antilles 195:3-162.

Pitt, W. C., and R. T. Sugihara. 2009. Spatial (foraging distance) and temporal (time and frequency of visitation) responses of marked small Indian mongooses (Herpsestes auropunctatus) to selected food baits in Hawai'i. Job Completion Report. USDA/APHIS/WS/National Wildlife Research Center, Hilo, Hawaii, 55 pp.

Quinn, J. H., and D. A. Whisson. 2005. The effects of anthropogenic food on the spatial behavior of small Indian mongooses (Herpestes javanicus) in a subtropical rainforest. J. Zool. 267:339-350.

Rosatte, R. C., D. Donovan, J. C. Davies, M. Allan, P. Bachmann, B. Stevenson, K. Sobey, L. Brown, A. Silver, K. Bennett, T. Buchanan, L. Brucs, M. Givson, A. Beresford, A. Beath, C. FehlnerGardiner, and K. Lawson. 2009. Aerial distribution of ONRAB baits as a tactic to control rabies in raccoons and striped skunks in Ontario, Canada. $J$. Wildlife Dis. 45:363-374.

Saunders, G., and S. Harris. 2000. Evaluation of attractants and bait preferences of captive red foxes (Vulpes vulpes). Wildlife Res. 27:237-243.

Seaman, G. A., and J. E. Randall. 1962. The mongoose as a predator in the Virgin Islands. J. Mammal. 43:544-546.

Slate, D., C. E. Rupprecht, J. A. Rooney, D. Donovan, D. H. Lein, and R. B. Chipman. 2005. Status of oral rabies vaccination in wild carnivores in the United States. Virus Res. 111:68-76.

Sugihara, R. T. 2009. Screeining trials to identify potential natural and artificial attractants, lures and bait substrates for introduced mongooses (Herpestes auropunctatus) in Hawaii. Unpublished final report, research protocol QA-1101. USDA/ APHIS/WS/National Wildlife Research Center, Hilo, Hawaii, 13 pp.

Weaver, P. L, and J. J. Schwagerl. 2008. Secondary forest succession and tree planting at the Laguna Cartagena and Cabo Rojo Wildlife Refuges in southwestern Puerto Rico. J. Hum. Env. 37:598603. 